\title{
Expression of luteinizing hormone genes in bovine conceptuses
}

\author{
C. J. Otieno, C. M. Wood, S. K. Tallam, A. M. Verrinder Gibbins \\ and J. S. Walton* \\ Department of Animal and Poultry Science, University of Guelph, Guelph, \\ Ontario N1G 2W1, Canada
}

RT-PCR analysis demonstrated that bovine conceptuses at days 16, 23 and 30 expressed LH- $\beta$-like and glycoprotein hormone $\alpha$-like transcript sequences; adult kidney, liver and brain produced predominantly unspliced products. Sequencing of the LH- $\beta$-like fragment (from conceptuses at day 30) indicated complete homology with the published sequence. In addition, ribonuclease protection assay of RNA samples from bovine conceptuses at day 30 with a bovine LH- $\beta$ probe revealed the presence of protected molecules that appeared to be full length. Northern blot analysis of total RNA from conceptuses at day 30 failed to demonstrate the presence of LH- $\beta$ or glycoprotein $\alpha$ subunit transcripts, whereas both transcripts were readily detected in adult pituitary RNA. Administration of hCG into the uterus of heifers from day 14 to day 16 of the oestrous cycle did not affect circulating progesterone concentrations, whereas the same dose increased progesterone concentrations $(P<0.05)$ when administered intravenously. These results indicate that the early bovine conceptus transcribes genes encoding $\mathrm{LH}-\alpha$ and $-\beta$ subunits, but at a level unlikely to be of physiological consequence.

\section{Introduction}

An important requirement for successful establishment of pregnancy in cattle is the extension of the lifespan of the corpus luteum to maintain progesterone secretion necessary for continued gestation. Maintenance of the corpus luteum is achieved by direct luteotrophic support from pituitary LH during the luteal phase, and from chorionic gonadotrophin in primates during pregnancy (Hearn, 1986; Webley and Hearn, 1994). In cattle, it is generally agreed that the corpus luteum of pregnancy is largely dependent on pituitary LH and, between day 16 and days 24-27 of pregnancy (Helmer et al., 1987), the conceptus synthesizes interferon $\tau$ to abrogate the luteolytic effects of $\mathrm{PGF}_{2 \alpha}$ from the uterus (Bazer et al., 1986; Godkin et al., 1988). As cows require a functional corpus luteum for the greater portion of gestation (Estergreen et al., 1967), and interferon $\tau$ is produced transiently (Helmer et al., 1987), the possibility of additional placental luteotrophic support in this species should not be ruled out. Other studies have provided preliminary evidence for bovine conceptus luteotrophins, in particular molecules with bovine LH (bLH)-like activity with molecular mass greater than that of pituitary bLH (Ailenberg and Shemesh, 1983; Hickey et al., 1989).

The present study investigated the transcription of bLH- $\alpha$ and $-\beta$ subunit mRNA using RT-PCR to determine whether bovine conceptuses synthesize bLH-like molecules during early development. Analysis of PCR products was

*Correspondence

Email: jswalton@uoguelph.ca performed using Southern blot analysis, restriction endonuclease digestion, ribonuclease protection analysis and sequencing. The potential physiological implications of bLH synthesis within the uterus were investigated further by examining the effect of administering small amounts of hCG either into the uterine lumen or into the circulation on circulating progesterone concentrations in an attempt to determine the likelihood of luteotrophic or luteolytic effects that could result from $\mathrm{LH}$ synthesis by the conceptus.

\section{Materials and Methods}

\section{Tissue collection and RNA isolation}

The tissue samples for RNA isolation were obtained from conceptuses recovered from beef cows immediately after they had been killed at one of four stages of gestation after artificial insemination: day 16 (eight sets of pooled samples), day 23 (six single whole samples), day 30 (16 conceptuses) and day 35 (12 conceptuses). The cows that were used to obtain conceptuses at day 16 were synchronized for oestrus and superovulated, whereas the cows that provided conceptuses at days 23, 30 and 35 were not superovulated. Adult tissues were also obtained from cattle immediately after they were killed, namely the anterior pituitary gland $(n=7)$, liver $(n=4)$, kidney $(n=4)$ and brain $(n=4)$. Conceptuses at day 16 from superovulated cows were flushed from the uterus and pooled for each analysis. Conceptuses at days 23 and 30 were obtained by dissection of the uterus. Conceptuses at day 23 were used as single whole samples for each analysis. Conceptuses at days 30 and 35 were dissected into allantois, embryo and chorion, each of which was analysed separately. 
All animal procedures were approved by the University Animal Care Committee in accordance with the regulations of the Canadian Committee for Animal Care. Total RNA was isolated from each sample immediately after recovery essentially as described by Maniatis et al. (1982).

\section{$R T-P C R$ using specific primers for $b L H-\alpha$ and $b L H-\beta$ subunits}

Total RNA (100 ng-2 $\mu \mathrm{g}$ ) from conceptuses and adult tissues was mixed with random primers (Gibco BRL, Burlington, $\mathrm{ON}$ ) in a proportion of $40 \mathrm{ng}$ primer per $\mu \mathrm{g}$ RNA and the volume was made up to $10 \mu \mathrm{l}$ with diethylpyrocarbonate (DEPC)-treated water. The sample was heated for 10 min at $70^{\circ} \mathrm{C}$, cooled immediately on ice and spun briefly to ensure the sample was at the bottom of the tube before storage. The mixture was stored on ice and combined with $5 \mu$ of $5 \times$ reverse transcription buffer (Gibco BRL), $2 \mu$ of $0.1 \mathrm{~mol}$ dithiothreitol (DTT) $\mathrm{I}^{-1}$ (Gibco BRL), $2 \mu \mathrm{l}$ of 10 mmol dNTP ${ }^{-1}$ (Pharmacia Biotech, Baie d'Urfe, Quebec), $40 \mathrm{U}$ RNAGuard RNase inhibitor (Pharmacia), $300 \mathrm{U}$ Moloney murine leukaemia virus RNase $\mathrm{H}^{-}$reverse transcriptase (M-MLV H- RT (Superscript) ${ }^{\mathrm{TM}}$; Gibco BRL) and DEPC-treated water to a volume of $25 \mu \mathrm{l}$. The sample was left for $10 \mathrm{~min}$ at room temperature followed by incubation for $1 \mathrm{~h}$ at $38^{\circ} \mathrm{C}$. The reaction products were heated at $95^{\circ} \mathrm{C}$ for $5 \mathrm{~min}$. A $3 \mu \mathrm{l}$ volume of the final reaction mixture was used for PCR analysis with primer pairs designed according to the published bovine DNA sequences for LH- $\beta$ (P1, P2) (Maurer, 1985; Virgin et al., 1985) and the glycoprotein hormone $\alpha$ subunit (P3, P4) (Goodwin et al., 1983; Nilson et al., 1983). The sequences of the primers are as follows: P1: 5' TGCCCTGTCTGTATCACTTT 3'; P2: 5' CCACGGGGAAGGAGACCATT 3'; P3: 5' GCAGCTGTCATTCTGGCCAT 3'; and P4: 5' GCACTGATAGATTGGAGCAT 3'. PCR analysis was performed using a carryover contamination prevention kit (Gibco BRL) that substituted deoxyuridine triphosphate (dUTP) for deoxythymidine triphosphate (dTTP) and used uracil DNA glycosylase (UDG) to destroy uracil-containing DNA from previous reactions (Erlich et al., 1991; Bebee et al., 1992). The reaction components were $10 \mu \mathrm{l}$ of $10 \times$ reaction buffer (100 mmol Tris- $\mathrm{HCl} \mathrm{I-1,} \mathrm{pH} 8.3$, and $500 \mathrm{mmol} \mathrm{KCl}$ $\mathrm{I}^{-1}$; Gibco BRL), $2 \mu \mathrm{l} \mathrm{dU}-\mathrm{dNTP} \operatorname{mix}\left(10 \mathrm{mmol} \mathrm{I}^{-1}\right.$ each of dATP, dCTP, dGTP and $20 \mathrm{mmol}$ dUTP $\mathrm{I}^{-1}$; Gibco BRL), $2 \mu \mathrm{l}$ 5' primer $(20 \mathrm{pmol}), 2 \mu \mathrm{l} 3^{\prime}$ primer $(20 \mathrm{pmol}), 1 \mathrm{ng}$ template DNA, $1 \mu \mathrm{l}$ UDG $(1 \mathrm{U}), 15 \mu \mathrm{IgCl}_{2}\left(10 \mathrm{mmol} \mathrm{I}^{-1}\right)$ and water to bring the final reaction volume to $100 \mu \mathrm{l}$. For each PCR, a 'no template' and a 'no reverse transcriptase' control was included. The solution was incubated at $37^{\circ} \mathrm{C}$ for $10 \mathrm{~min}$ followed by incubation at $94^{\circ} \mathrm{C}$ for $10 \mathrm{~min}$. Taq DNA polymerase (2.5 U; Promega Inc., Madison, WI) was added and the mixture was subjected to 40 cycles of amplification, each consisting of $94^{\circ} \mathrm{C}$ for $30 \mathrm{~s}$ (denaturation), $55^{\circ} \mathrm{C}$ for $60 \mathrm{~s}$ (annealing) and $72^{\circ} \mathrm{C}$ for $30 \mathrm{~s}$ (primer extension). At the end of the temperature cycles the solution was incubated at $72{ }^{\circ} \mathrm{C}$ for $15 \mathrm{~min}$. The PCR products (20 $\mu$ l samples) were subjected to electrophoresis on $2 \%(\mathrm{w} / \mathrm{v})$ agarose gels containing $1 \mu \mathrm{g}$ ethidium bromide $\mathrm{ml}^{-1}$ with a DNA molecular size marker (Gibco BRL), and the amplified fragments were viewed under ultraviolet light and photographed.

\section{Restriction endonuclease digestion of $P C R$ products}

Restriction endonuclease digestion was performed to verify the identity of the amplified cDNA fragments. The reaction mixture consisted of $15 \mu \mathrm{l}$ DNA, $2 \mu \mathrm{l}$ of $10 \times$ restriction endonuclease buffer (buffer $\mathrm{A}$ for $\mathrm{Alu} \mathrm{I}$ or buffer L for Hpa II; Boehringer Mannheim, Indianapolis, IN), $2 \mu \mathrm{l}$ restriction endonuclease (Hpa II for LH- $\beta$ products or Alu I for glycoprotein hormone $\alpha$ subunit products), $0.8 \mu \mathrm{l}$ spermidine $\left(100 \mathrm{mmol}^{-1}\right)$ and water to a final volume of $20 \mu \mathrm{l}$. The samples were incubated at $37^{\circ} \mathrm{C}$ for $5-24 \mathrm{~h}$. At the end of the reaction the digests were resolved on $2 \%$ $(\mathrm{w} / \mathrm{v})$ agarose gels.

\section{Southern blot analysis of RT-PCR products using digoxigenin-labelled cDNA probes}

After electrophoresis of the amplified fragments, the agarose gel was immersed twice $(2 \times 15 \mathrm{~min})$ in denaturation solution $\left(0.5 \mathrm{~mol} \mathrm{NaOH} \mathrm{I}{ }^{-1}, 1.5 \mathrm{~mol} \mathrm{NaCl}{ }^{-1}\right)$ at room temperature with gentle shaking. The gel was rinsed with water and submerged in neutralization solution $(0.5$ mol Tris-Cl I-1, $\mathrm{pH} 7.5,3 \mathrm{~mol} \mathrm{NaCl} \mathrm{I-1}$ ) for $2 \times 15 \mathrm{~min}$ at room temperature. The DNA was transferred from the gel to positively charged nylon membranes (Boehringer Mannheim) by capillary transfer in $20 \times$ saline-sodium citrate buffer (SSC) overnight, as described by Sambrook et al. (1989). After transfer the DNA was fixed on the membrane by heating in a vacuum oven at $80^{\circ} \mathrm{C}$ for $2 \mathrm{~h}$. Hybridization was performed as described for the northern blotting (see below) except that for the Southern blot incubations with both the prehybridization solution $(5 \times \mathrm{SSC}, \quad 1 \% \quad(\mathrm{w} / \mathrm{v})$ blocking reagent, $0.1 \% \quad(\mathrm{w} / \mathrm{v}) \quad \mathrm{N}$ lauroylsarcosine, $0.02 \%(\mathrm{w} / \mathrm{v}) \mathrm{SDS}$ ) and the hybridization solution were performed at $68^{\circ} \mathrm{C}$. Chemiluminescent detection was performed as for the northern blot except that the Southern blot was blocked using buffer $2(1 \%(\mathrm{w} / \mathrm{v})$ blocking reagent in buffer 1; 100 mmol maleic acid I-1, 150 mmol NaCl I-1, pH 7.5) for $1 \mathrm{~h}$ and was washed for $2 \times 15$ min in buffer 1 after the antibody incubation step.

\section{Northern blot analysis}

Eight microlitres of deionized formamide, $2 \mu$ of $20 \times$ running buffer (800 mmol MOPS I-1, $200 \mathrm{mmol}$ sodium acetate $\mathrm{I}^{-1}, 20 \mathrm{mmol}$ EDTA $\left.\mathrm{I}^{-1}, \mathrm{pH} 7\right), 4 \mu \mathrm{l}$ formaldehyde $\left(12.3 \mathrm{~mol} \mathrm{I}^{-1}, 37 \%(\mathrm{v} / \mathrm{v})\right.$ solution in water; Fisher Scientific, Unionville, ON) and $1 \mu \mathrm{l}$ ethidium bromide solution ( $1 \mu g \mathrm{I}^{-1}$ water) were added to each total RNA sample $(20 \mu \mathrm{g})$ from the conceptuses at day 30 and the adult tissue and to a $5 \mu \mathrm{l}$ sample of digoxigenin-labelled RNA molecular mass marker III (Boehringer Mannheim). The 
samples were incubated for $15 \mathrm{~min}$ at $65^{\circ} \mathrm{C}$ followed by the addition of $1.5 \mu \mathrm{l}$ loading buffer $(50 \%$ (v/v) glycerol, $0.2 \%$ $(\mathrm{w} / \mathrm{v})$ bromophenol blue and $0.2 \%(\mathrm{w} / \mathrm{v})$ xylene cyanol). The samples were loaded into the wells of a $3 \mathrm{~mm}$ thick $1 \%$ $(\mathrm{w} / \mathrm{v})$ agarose-formaldehyde gel covered with $1 \times$ running buffer and subjected to electrophoresis at $60 \mathrm{~V}$ for $2 \mathrm{~h}$. The RNA bands were viewed over ultraviolet light and the integrity of the ribosomal RNA was confirmed.

After electrophoresis, the agarose-formaldehyde gel was equilibrated by soaking in $20 \times$ SSC buffer for $2 \times 15 \mathrm{~min}$. RNA was blotted to a positively charged nylon membrane (Boehringer Mannheim) by capillary transfer in $20 \times$ SSC buffer for 15-24 $\mathrm{h}$ at room temperature, as described by Sambrook et al. (1989). After transfer the membrane was heated in a vacuum oven at $80^{\circ} \mathrm{C}$ for $2 \mathrm{~h}$ to fix the RNA and was stored in a vacuum-sealed plastic bag.

Hybridization was performed using the procedure and reagents provided with the digoxigenin DNA labelling and detection kit (Boehringer Mannheim). The blot was placed in a hybridization bag containing $20 \mathrm{ml}$ northern prehybridization solution $(5 \times \mathrm{SSC}, 50 \%(\mathrm{v} / \mathrm{v})$ formamide, $7 \%(\mathrm{w} / \mathrm{v})$ SDS, $0.1 \%(\mathrm{w} / \mathrm{v}) \mathrm{N}$-lauroylsarcosine and $2 \%(\mathrm{w} / \mathrm{v})$ blocking reagent) per $100 \mathrm{~cm}^{2}$ of membrane surface area and was incubated at $42^{\circ} \mathrm{C}$ for $2 \mathrm{~h}$ with gentle shaking. The probes used were: pSP65- $\beta$ bLH containing a bovine $\mathrm{LH}-\beta$ cDNA insert cloned into the Eco RI site of pSP65 (Maurer, 1985; provided by R. A. Maurer, Department of Physiology and Biophysics, University of lowa, lowa City, IA); $\mathrm{pB} \alpha$ consisting of a bovine pituitary glycoprotein hormone $\alpha$ subunit cDNA insert cloned into the Pst I site of pBR 322 (Nilson et al., 1983; provided by J. H. Nilson, Department of Pharmacology and Medicine, Case Western Reserve University, Cleveland, $\mathrm{OH})$; and pBS SK(+) actin, which was constructed by subcloning a bovine $\gamma$ actin cDNA insert from an original pBR 322-based clone (Degan et al., 1983) into the Pst I site of pBluescript SK(+) ${ }^{\mathrm{TM}}$ (Stratagene Cloning Systems, La Jolla, CA), and was provided by D. Morris (Department of Biochemistry, University of Washington, Seattle, WA). Digoxigenin-labelled cDNA probe ( $\mathrm{LH}-\beta$, glycoprotein hormone $\alpha$ subunit or $\gamma$ actin) was denatured by heating in a boiling waterbath for $10 \mathrm{~min}$ and chilled immediately on ice, after which it was added to $10 \mathrm{ml}$ prehybridization solution at a concentration of 5-25 ng ml-1. The northern prehybridization solution was discarded from the bag and was replaced with the hybridization solution containing the probe. The bag was incubated at $42^{\circ} \mathrm{C}$ overnight with gentle shaking. The membrane was placed in a Pyrex dish and was washed $(2 \times 5 \mathrm{~min})$ in $2 \times$ wash solution $(2 \times \mathrm{SSC}, 0.1 \%(\mathrm{w} / \mathrm{v}) \mathrm{SDS})$ at room temperature, after which it was washed $(2 \times 15 \mathrm{~min})$ in $0.5 \times$ wash solution $(0.5 \times \mathrm{SSC}, 0.1 \% \mathrm{SDS})$ at $68^{\circ} \mathrm{C}$.

\section{Chemiluminescent detection}

Chemiluminescent detection was performed using a modified version of the method of Lanzillo (1991) according to the instructions provided with the digoxigenin
DNA labelling and detection kit (Boehringer Mannheim). All incubations were performed at room temperature with gentle agitation. After post-hybridization washes the membrane was equilibrated in $50 \mathrm{ml}$ buffer 1 per $100 \mathrm{~cm}^{2}$ for $1 \mathrm{~min}$. The membrane was then incubated in $50 \mathrm{ml}$ northern blocking solution $(7 \%(\mathrm{w} / \mathrm{v})$ blocking reagent in buffer 1) for $2 \mathrm{~h}$. Before completion of the blocking step, the anti-digoxigenin alkaline phosphatase (Boehringer Mannheim) was diluted to $150 \mathrm{mU} \mathrm{ml}^{-1}$ (1:5000) in $30 \mathrm{ml}$ blocking solution per $100 \mathrm{~cm}^{2}$ membrane surface area. The blot was incubated for $30 \mathrm{~min}$ in the antibody solution, followed by $3 \times 20$ min washes in $200 \mathrm{ml}$ buffer 1 , after which the membrane was equilibrated for 5 min in buffer 3 (100 mmol Tris- $\mathrm{HCl} \mathrm{I}{ }^{-1}, \mathrm{pH} 9.5,100 \mathrm{mmol} \mathrm{NaCl} \mathrm{I}{ }^{-1}$, $\left.50 \mathrm{mmol} \mathrm{MgCl}_{2} \mathrm{I}^{-1}\right)$. The membrane was placed between two sheets of acetate and $0.5 \mathrm{ml}$ per $100 \mathrm{~cm}^{2}$ of Lumigen ${ }^{\mathrm{TM}}$ PPD (Boehringer Mannheim) diluted 1:100 in buffer 3 was added and distributed evenly between the upper sheet of acetate and the upper surface of the membrane. For detection of chemiluminescence, the membrane was placed in a cassette for exposure of X-ray film (Kodak XOMAT AR-5; Medtech, Mississauga, Ontario) for 1-12 h in the dark at room temperature.

\section{Ribonuclease protection analysis}

Ribonuclease protection analysis was performed essentially according to Lee and Costlow (1987) to determine the presence of full-length LH- $\beta$ transcripts. The plasmid pSP65- $\beta$ bLH contained a 600 bp bovine LH- $\beta$ cDNA insert oriented such that an antisense RNA transcript was generated with SP6 RNA polymerase (Maurer, 1985). The second plasmid, pBS SK(+) actin, included a $1.3 \mathrm{kbp}$ bovine $\gamma$ actin cDNA insert (Degen et al., 1983) with an orientation, as determined by Hind III digestion, allowing transcription of an RNA probe using T7 RNA polymerase. The $564 \mathrm{bp}$ glycoprotein $\alpha$ subunit cDNA insert from a $\mathrm{pB} \alpha$ clone (Nilson et al., 1983) was subcloned into the Sma I site of pBluescript $\mathrm{SK}(+)^{\mathrm{TM}}$, which has transcription promoters, to enable synthesis of an RNA probe. The three plasmids were digested at the $5^{\prime}$ ends of the inserts, using Xba I for pSP65$\beta b L H, B s t$ Ell for pBS SK(+) actin and Pvu II for pBS SK(+)- $\alpha$, to enable transcription of antisense RNA probes. A digoxigenin RNA labelling kit (Boehringer Mannheim) was used to transcribe and label the RNA simultaneously.

Twenty micrograms of total RNA sample from day 30 conceptuses and adult tissues was dissolved in $20 \mu \mathrm{l}$ hybridization buffer $(80 \%(\mathrm{v} / \mathrm{v})$ deionized formamide, 100 mmol sodium citrate $\mathrm{I}^{-1}$, $\mathrm{pH}$ 6.4, $300 \mathrm{mmol}$ sodium acetate $\mathrm{I}^{-1}$, pH 6.4, 1 mmol EDTA I-1; Soln A, Ambion kit, Ambion, Austin, TX). The samples were incubated with DNase I (20 U; Gibco BRL) for $15 \mathrm{~min}$ at $37^{\circ} \mathrm{C}$ to remove possible contaminating genomic DNA. The samples were then mixed with 600 pg digoxigenin-labelled RNA probe (bLH$\beta, \alpha$ subunit or $\gamma$ actin) before ribonuclease protection analysis using the ribonuclease protection kit (RPA IIM; Ambion, Austin, TX). 
(a) MPAECAECAECKLB

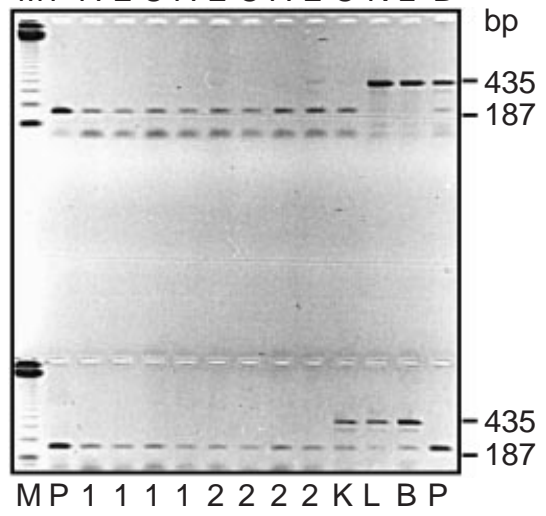

(b) $P A E C A E C A E C K L B M$

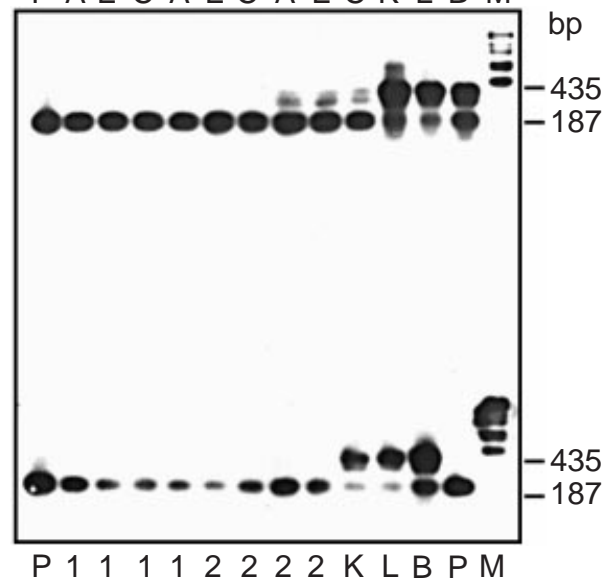

(c) $M P P A A E E C C K K L L B B$ $u$ d $u$ d $u$ d $u$ d $u$ d $u$ d $u$ d

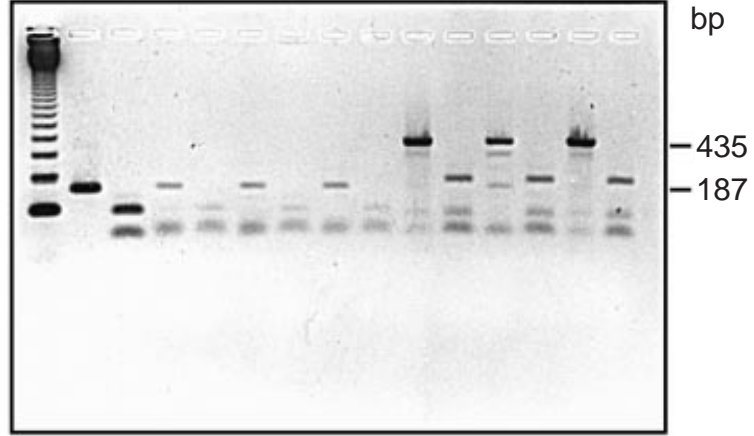

Fig. 1. (a) Detection of $L H-\beta$ transcripts in bovine conceptuses by RT-PCR. Sizes of the products expected from spliced (187 bp) and unspliced (435 bp) LH- $\beta$ transcripts are indicated on the right-hand side of the gel. The total RNA samples used for RT-PCR in the upper (conceptuses at day 30, $n=3$ ) and lower (conceptuses at days 16 and 23, $n=4$ ) parts of the gel are as indicated. (b) Hybridization of a bLH- $\beta$ cDNA probe to bovine conceptus and adult tissue RT-PCR products. The RT-PCR products shown in (a) were transferred to positively charged nylon membrane and hybridized with digoxigenin-labelled bLH- $\beta$ cDNA probe. (c) Verification of the identity of RT-PCR products from bovine

\section{Sequencing of amplified $L H-\beta$ DNA fragments}

LH- $\beta$ DNA fragments amplified using primers $\mathrm{P} 1$ and $\mathrm{P} 2$ from chorion and allantois of conceptuses from days 33 and 35 were sequenced using the $\mathrm{ABI}-377$ prism sequencer (Perkin Elmer Corporation, Alameda, CA) using primers P1 and P2.

\section{Intrauterine administration of $h C G$}

Holstein heifers ( $n=22$, age 12-15 months) were synchronized into oestrus using two injections (500 $\mu \mathrm{g}$ i.m.) of cloprostenol (Estrumate, Coopers Agropharm Inc., Willowdale, Ontario) 11 days apart and were assigned randomly to four treatment groups. On days 14-16 of the synchronized oestrous cycle, the animals received intravenous (hCG-IV, $n=7$ ) or intrauterine (hCG-IU, $n=7$ ) administration of 200 iu highly purified hCG (CR-127; National Hormone and Pituitary Program, Torrance, CA) once a day. Control groups received equivalent intravenous (Sal-IV, $n=4$ ) or intrauterine (Sal-IU, $n=4$ ) volumes of saline. The intrauterine administration of hCG or saline was performed using a $0.5 \mathrm{ml}$ Cassou pipette inserted into the uterine body by cervical manipulation per rectum. Blood samples were collected once a day by coccygeal venepuncture into $10 \mathrm{ml}$ heparinized vacutainer tubes (BecktonDickinson, Mississauga, Ontario) for determination of plasma progesterone concentrations. All animals were equipped with indwelling jugular catheters on day 13 to facilitate frequent blood sampling on days 14-16. Blood samples $(10 \mathrm{ml})$ were also collected every $2 \mathrm{~h}$ starting before hCG treatment to $10 \mathrm{~h}$ after treatment. All the blood samples were centrifuged at $1500 \mathrm{~g}$ for $20 \mathrm{~min}$ and plasma was stored at $-20^{\circ} \mathrm{C}$ until progesterone concentrations in the plasma were determined using a validated radioimmunoassay (Robinson et al., 1989). Ovarian activity was monitored each day from day 12 to day 26 using transrectal ultrasonography (Aloka SSD-500 real-time B-mode linear array ultrasound scanner equipped with a 5.0 MHz transducer; Aloka Co. Ltd, Tokyo).

Plasma progesterone concentrations from each day were analysed by repeated measurement ANOVA using the general linear model procedure of SAS (SAS, 1990). Variables containing single observations in time were examined for treatment effects by one-way ANOVA.

conceptuses at day 30 in (a) using restriction endonuclease digestion analysis. Examples of the typical pattern of Hpa IIdigested bLH- $\beta$-like RT-PCR products from conceptuses at day 30 displaying the expected sizes for unspliced (212, 91, 50, 44 and $38 \mathrm{bp})$ and spliced (105, 44 and $38 \mathrm{bp}$ ) transcripts are shown. $\mathrm{P}$ : pituitary; A: allantois; $\mathrm{B}$ : brain; $\mathrm{C}$ : chorion; $\mathrm{d}$ : digested; E: embryo; K: kidney; L: liver; M: $(\mathrm{a}, \mathrm{c}) 123$ bp DNA size marker, (b) digoxigenin-labelled DNA size marker; u: undigested; 1: conceptus at day $16 ; 2$ : conceptus at day 23 . 


\section{Results}

\section{$R T-P C R$ using bLH- $\beta$-specific primers}

RT-PCR results obtained using the LH- $\beta$ primers are shown (Fig. 1a). The expected 187 bp band was present in the tissues from bovine conceptuses at day 30 (allantois, embryo and chorion) and in the adult pituitary. The lower band appearing in all the samples represents unused primers. The adult kidney, liver and brain tissues yielded predominantly a fragment of larger size (435 bp), with comparatively fewer, if any, $187 \mathrm{bp}$ fragments and one additional faint band just below the $435 \mathrm{bp}$ fragment. Likewise, the expected $187 \mathrm{bp}$ fragment was present in conceptus samples from day 16 (four pooled sets) and day 23 (four whole singles) (Fig. 1a). Southern blot analysis displayed strong hybridization of the 187 bp fragment from conceptuses at days 16, 23 and 30 with the bLH- $\beta$ cDNA probe (Fig. 1b). The RT-PCR products from the adult kidney, liver and brain tissues showed hybridization predominantly at the $435 \mathrm{bp}$ fragment. Restriction endonuclease digestion with Hpa II of the RT-PCR products resulted in fragments of expected sizes for pituitary and conceptus $(105,44$ and $38 \mathrm{bp})$ and for kidney, liver and brain (212, 91, 50, 44 and 38 bp) products (Maurer, 1985; Virgin et al., 1985) (Fig. 1C). The amplified fragments of LH$\beta$ DNA were sequenced using the $5^{\prime}$ and $3^{\prime} \mathrm{LH}-\beta$ primers (P1 and P2). The forward and reverse sequences were compared with the bovine LH- $\beta$ nucleotide sequence published in GenBank, using PC GENE ${ }^{\circledR}$ (IntelliGenetics, Inc., Mountain View, CA). Combining the forward and reverse nucleotide information into one sequence allowed complete $(100 \%)$ alignment of pituitary, allantois- and chorion-amplified sequences with the published $187 \mathrm{bp}$ $\mathrm{LH}-\beta$ nucleotide sequence between primers $\mathrm{P} 1$ and $\mathrm{P} 2$.

\section{$R T-P C R$ using bovine glycoprotein hormone $\alpha$-specific primers}

The PCR products generated using the glycoprotein hormone $\alpha$ subunit primers for the same reverse-transcribed samples as used for the LH- $\beta$ products are shown (Fig. 2). The expected $147 \mathrm{bp}$ band was observed in the different tissues of conceptuses at day 30 (allantois, embryo and chorion), similar to that for the adult pituitary. The adult kidney, liver and brain yielded predominantly amplified products of $1.2 \mathrm{kbp}$. In addition, other intermediate bands were observed. Conceptuses at days 16 and 23 displayed a similar pattern of expression of the $\alpha$-like transcripts to that observed for the conceptuses at day 30, yielding predominantly the expected 147 bp band. Southern blot analysis and restriction endonuclease digestion with Alu I were used to confirm the identity of the amplified products (data not shown).

\section{Northern blot analysis}

Bovine pituitary RNA of approximately 700 bases elicited a strong hybridization signal with the bLH- $\beta$ cDNA

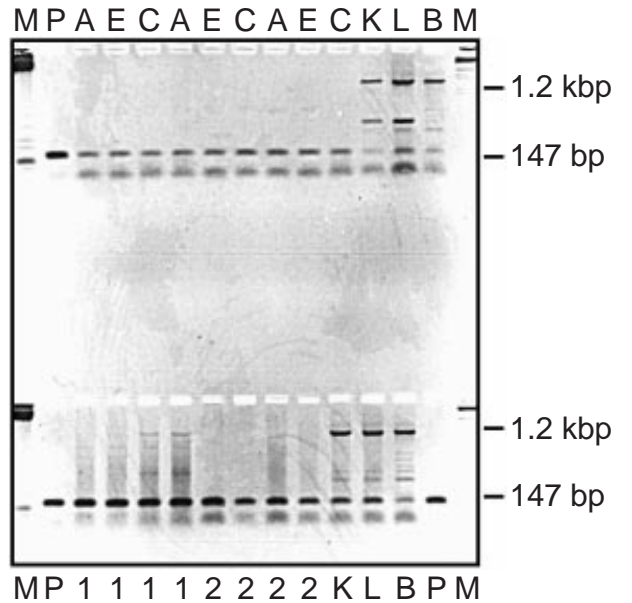

Fig. 2. Detection of bovine glycoprotein hormone $\alpha$ subunit transcripts in bovine conceptuses by RT-PCR. Sizes of the products expected from completely spliced (147 bp) and unspliced (1.2 kbp) bovine glycoprotein hormone $\alpha$ subunit transcripts are indicated on the right-hand side of the gel. The total RNA samples used for RT-PCR in the upper (conceptuses at day 30) and lower (conceptuses at days 16 and 23) parts of the gel are as indicated. A: allantois; B: brain; C: chorion; E: embryo; K: kidney; L: liver; M: 123 bp DNA size marker; P: pituitary; 1 : conceptus at day 16 ; 2 : conceptus at day 23.

probe in northern blot analysis, whereas the RNA from conceptuses at day 30 and from adult kidney, liver and brain tissue did not hybridize. Re-probing of the same blot with the bovine $\gamma$ actin cDNA probe revealed transcripts of approximately $2 \mathrm{~kb}$ in all the samples examined. Similar results were obtained when parallel samples were hybridized with the glycoprotein hormone $\alpha$ subunit cDNA probe: pituitary RNA of approximately 730 bases yielded a signal, whereas there was no hybridization to the conceptus or other tissue samples.

\section{Ribonuclease protection analysis}

Like the adult pituitary, but unlike the kidney, all the RNA samples from the conceptuses at day 30 appeared to protect a fragment of the size expected from full-length bLH- $\beta$ transcripts (approximately 600 bases) (Fig. 3). However, the conceptus product was of very low intensity. Hybridization of parallel samples with a bovine $\gamma$ actin RNA probe as a control revealed the presence of a protected fragment of the size $(1.1 \mathrm{~kb})$ expected for full-length $\gamma$ actin transcripts.

\section{Intrauterine administration of hCG}

Intravenous administration of 200 iu hCG from day 14 to day 16 increased circulating concentrations of progesterone on days 16, 17 and 18 ( $P<0.05$; Fig. 4$)$. However, infusion of the same dose of hCG into the uterus or the administration of saline (pooled by route of administration) 


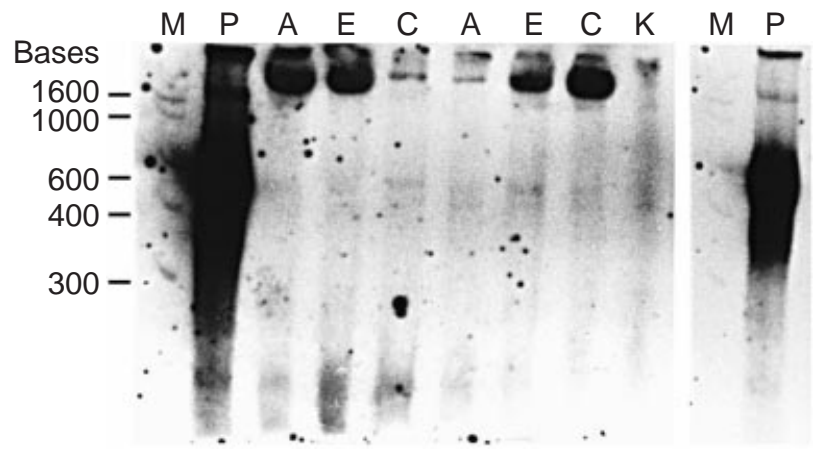

Fig. 3. Ribonuclease protection analysis of $b L H-\beta$ RNA probe with total RNA from bovine conceptuses at day 30 and adult tissue. Total RNA $(20 \mu \mathrm{g})$ from bovine conceptuses at day $30(n=2)$ and adult tissues was hybridized with 600 pg digoxigenin-labelled bLH- $\beta$ RNA, followed by ribonuclease digestion, polyacrylamide gel electrophoresis, electroblotting to positively charged nylon membrane and chemiluminescent detection. A: allantois; C: chorion; E: embryo; K: kidney; M: digoxigenin-labelled RNA size marker; $\mathrm{P}$ : pituitary. $\mathrm{M}$ and $\mathrm{P}$ on the right-hand side are $\mathrm{M}$ and $\mathrm{P}$ of the left-hand side after shorter exposure of the film.

was without effect. There were also no differences among treatments in the size or progression of either the existing corpus luteum or the ovulatory dominant follicle during or after administration of hCG or saline.

\section{Discussion}

RT-PCR analysis of total RNA from bovine conceptuses at days 16,23 and 30 using primers for bLH- $\beta$ resulted in amplified fragments of $187 \mathrm{bp}$, similar to those from the adult pituitary gland. On the basis of the published bovine LH- $\beta$ DNA sequences (Maurer, 1985; Virgin et al., 1985), the primers should amplify fragments of $187 \mathrm{bp}$ for cDNA from processed bLH- $\beta$ transcripts. Detection of bLH-like transcripts at day 30 in the chorion might be expected, as primate conceptuses synthesize hCG in the chorion (Hearn, 1986). The expression of $\mathrm{LH}$-like transcripts in the allantois is consistent with studies that demonstrated the presence of a luteotrophic glycoprotein in allantoic fluid from day 24 to day 37 in bovine conceptuses (Hickey et al., 1989). Although the embryonic pituitary gland is not visible before week 12 of gestation in humans, appearance of the pituitary primordium has been demonstrated using ultrastructural studies in human embryos at week 4 of pregnancy (Stefanovic et al., 1993), possibly explaining the presence of bLH-like transcripts in the embryo tissue at day 30, given the similarities in the duration of gestation between humans and cows.

The expected size for the RT-PCR products of unprocessed bLH- $\beta$ transcripts obtained using primers P1 and P2 is 435 bp (Maurer, 1985; Virgin et al., 1985). The adult kidney, liver and brain tissues generated mainly fragments of larger size (435 bp), which represent products

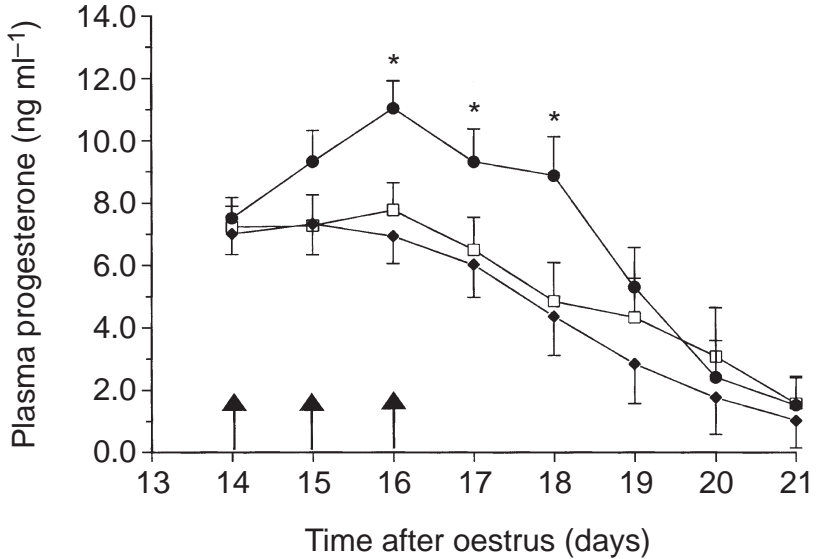

Fig. 4. Plasma concentrations of progesterone (mean \pm SEM) of heifers that received daily intravenous injection of 200 iu hCG $(\boldsymbol{\bullet}$, $n=7)$, intrauterine infusion of 200 iu hCG $(\bullet, n=7)$ or equivalent volume of saline ( $\square, n=8)$; data pooled from intravenous saline ( $n$ $=4$ ) and intrauterine saline $(n=4)$ on days $14-16$ (indicated by arrows). Progesterone concentrations before treatment on day 13 were used as a covariate for statistical analysis. Asterisks indicate means from the intravenous hCG group that are significantly different from the other groups $(P<0.05)$.

from unprocessed transcripts, with fewer, if any, products from processed transcripts. Southern blot analysis, using a bLH- $\beta$ cDNA probe (Maurer, 1985) and performed under stringent conditions that allow hybridization of only homologous sequences (Sambrook et al., 1989), confirmed the specificity of the RT-PCR products. Further verification using restriction endonucleases that have sequence-specific sites for bLH- $\beta$ (Virgin et al., 1985) and sequencing confirmed that the amplified fragments are identical to $\mathrm{LH}-\beta$ cDNA in this region of the gene.

Examination of total RNA from bovine conceptuses at days 16,23 and 30 by RT-PCR using the glycoprotein hormone $\alpha$ primers resulted in amplified fragments of 147 $\mathrm{bp}$, similar to those produced using the adult pituitary gland. On the basis of published DNA sequences for the bovine glycoprotein hormone $\alpha$ subunit (Goodwin et al., 1983; Nilson et al., 1983), these primers should amplify fragments of $147 \mathrm{bp}$ for cDNA from processed bovine glycoprotein hormone $\alpha$ subunit transcripts. Detection of conceptus $\alpha$ subunit-like transcripts lends support to the contention that the conceptus bLH- $\alpha$ - and - $\beta$-like transcripts could result in functional LH synthesis, as both subunits are required for the assembly of the glycoprotein (Pierce and Parsons, 1981).

Therefore, the experiments using RT-PCR demonstrate that bovine conceptuses at days 16, 23 and 30 express both $\mathrm{LH}-\beta$-like and glycoprotein hormone $\alpha$-like transcripts that appear to be processed. However, amplification by PCR of internal sequences does not prove that full-length transcripts are present; therefore, northern blot analysis was performed. Northern blot analysis of total RNA from bovine 
conceptuses at day 30 did not demonstrate the presence of bLH- $\beta$ or bovine glycoprotein $\alpha$ subunit transcripts, whereas both transcripts were readily detected in the adult pituitary. These results imply that if there are LH- $\beta$ and glycoprotein $\alpha$ subunit transcripts in the bovine conceptus, they are considerably less abundant than in the pituitary. Therefore, evidence for the presence of full-length $\mathrm{LH}-\beta$ transcripts in bovine conceptuses was sought using the more sensitive ribonuclease protection analysis.

Solution hybridization analysis of total RNA from bovine conceptuses at day 30 with an RNA probe transcribed from bLH- $\beta$ cDNA (Maurer, 1985) revealed a 600 base protected fragment, the approximate size expected for full-length mRNA, but in very low amounts. Similar results were observed for the glycoprotein $\alpha$ subunit, indicating that bovine conceptuses at day 30 express full-length processed LH- $\alpha$ - and $-\beta$-like transcripts.

Therefore, the present study provides evidence for the presence of bLH- $\beta$-like and glycoprotein hormone $\alpha$-like transcripts in bovine conceptuses. If the conceptus synthesizes glycoprotein from the LH-like transcripts, albeit in small amounts, the potential role of this $\mathrm{LH}$ is worthy of further consideration. Conceptus LH-like glycoproteins could have a paracrine role within the conceptus or on the uterus, or an endocrine role on the corpus luteum. These functions would require adequate concentrations and transport of the glycoproteins and the presence of $\mathrm{LH}-\mathrm{hCG}$ receptors on the respective target cells (Pierce and Parsons, 1981).

The presence of uterine $\mathrm{LH}-\mathrm{hCG}$ receptors has been demonstrated in pigs (Ziecik et al., 1986), rabbits (Jensen and Odell, 1988; Sawitzke and Odell, 1991), humans (Reshef et al., 1990), rats (Bonnamy et al., 1990, 1993) and cows (Freidman et al., 1995). The presence of LH-hCG receptors in pregnant pig uterus indicates that these receptors could mediate the direct effects of $\mathrm{LH}$, or a conceptus $\mathrm{LH}$-like substance, for instance in the relaxation of myometrial smooth muscles (Ziecik et al., 1986) or in the modulation of progesterone concentrations in the endometrium (Bonnamy et al., 1990). Moreover, the observation that hCG administration increases uterine blood flow in gilts (Ziecik et al., 1992) strengthens the concept that a paracrine effect of conceptus LH on uterine blood flow in cows could be mediated through the uterine LH-hCG receptors described by Friedman et al. (1995).

In addition to a local effect on the uterus, the possibility that potential glycoprotein products of the conceptus bLHlike transcripts have endocrine effects on the corpus luteum was considered. In general, an endocrine role would require synthesis of sufficient amounts of the bLH-like glycoprotein to overcome the dilution in systemic circulation and stimulate progesterone synthesis by the corpus luteum. Nevertheless, evidence is available for luteotrophic effects of conceptus products, as studies have demonstrated that both plasma and milk progesterone concentration are higher in pregnant compared with nonpregnant cows during the early luteal phase after ovulation, which is before the onset of luteolysis (days 16-17) and the secretion of interferon $\tau$ (Henricks et al., 1970; Bulman and Lamming, 1978; Lukaszewska and Hansel, 1980). Evidence for direct LH-like effects of bovine conceptus products on the corpus luteum also stems from studies that demonstrated the ability of bovine conceptus extracts or secretions to stimulate progesterone secretion by bovine luteal cells (Beal et al., 1981; Ailenberg and Shemesh, 1983; Hickey et al., 1989; Izhar and Shemesh, 1989; Thibodeaux et al., 1994).

In an attempt to determine whether a small amount of bLH from the uterus was capable of exerting a luteotrophic response, hCG was administered directly into the uterus. As luteal and endometrial $\mathrm{LH}$ receptors have similar affinity for, and responsiveness to, hCG, this was used as a longeracting stimulus. At a dose of hCG that stimulated progesterone synthesis by the existing corpus luteum when infused intravenously, there was no effect of the intrauterine administration of hCG. As the uterus at this time contains a significant population of LH-hCG receptors, the uterus could act to prevent escape of hCG to the vasculature and thus prevent action at the corpus luteum. As the endometrial LH-hCG receptors are coupled to cyclooxygenase activity and prostaglandin synthesis (Friedman et al., 1995; Stepien et al., 1999), the absence of a luteolytic effect is also of interest.

Therefore, these data support the conclusion that, at the level of transcription observed using RT-PCR and ribonuclease protection analysis, synthesis of active LH by the conceptus can have only physiological significance as a local mediator either within the developing conceptus or, possibly more likely, through interaction with the endometrial receptors for LH-hCG to influence uterine contractility or blood flow.

In summary, evidence is presented to indicate that there is expression of $\mathrm{LH}-\alpha$ and $-\beta$ subunit genes by bovine conceptuses between day 16 and day 35 of gestation, albeit at very low levels. At this level of detection, expression may be either non-specific 'leaky' transcription or low level extra-pituitary gene expression as reported in human leucocytes (Hotakainen et al., 2000). As intrauterine administration of hCG had no effect on luteal function, it appears that any local synthesis of small amounts of $\mathrm{LH}$ would have only local physiological significance as a paracrine influence either on the developing conceptus or on the epithelium of the endometrium.

This research was supported by the Natural Sciences and Engineering Research Council of Canada and by the Ontario Ministry of Agriculture, Food and Rural Affairs. The authors are grateful to R. A. Maurer and J. H. Nilson for gifts of $\mathrm{LH} \beta$ and glycoprotein $\alpha$ cDNA, D. R. Morris for $\gamma$ actin cDNA and to the National Hormone and Pituitary Program for purified hCG.

\section{References}

Ailenberg $\mathbf{M}$ and Shemesh $\mathbf{M}$ (1983) Partial purification of a chorionic gonadotrophin-like protein from bovine cotyledons Biology of Reproduction 28 517-522 
Bazer FW, Vallet JL, Roberts RM, Sharp DC and Thatcher WW (1986) Role of conceptus secretory products in establishment of pregnancy Journal of Reproduction and Fertility 76 841-850

Beal WE, Lukaszewska JH and Hansel W (1981) Luteotropic effects of bovine blastocysts Journal of Animal Science 52 567-574

Bebee RL, Thornton CG, Hartley JL and Rashtchian A (1992) Contamination-free polymerase chain reaction: endonuclease cleavage and cloning of dU-PCR products Focus 14 53-56

Bonnamy P-J, Benhaim A and Leymarie P (1990) Estrous cycle-related changes of high affinity luteinizing hormone/human chorionic gonadotropin binding sites in the rat uterus Endocrinology $\mathbf{1 2 6}$ 1264-1269

Bonnamy P-J, Benhaim A and Leymarie P (1993) Uterine luteinizing hormone/human chorionic gonadotropin-binding sites in the early pregnant rat uterus: evidence for total occupancy in the periimplantation period Endocrinology 132 1240-1246

Bulman DC and Lamming GE (1978) Milk progesterone levels in relation to conception, repeat breeding and factors influencing acyclicity in dairy cows Journal of Reproduction and Fertility $\mathbf{5 4} 447-458$

Degen JL, Neubauer MG, Degen SJF, Seyfried CE and Morris DR (1983) Regulation of protein synthesis in mitogen-activated bovine lymphocytes: analysis of actin-specific and total mRNA accumulation and utilization Journal of Biological Chemistry 25812 153-12 162

Erlich HA, Gelfand D and Sninsky JJ (1991) Recent advances in the polymerase chain reaction Science 252 1643-1651

Estergreen VL, Frost OL, Gomes WR, Erb RE and Bullard JF (1967) Effect of ovariectomy on pregnancy maintenance and parturition in dairy cattle Journal of Dairy Science $\mathbf{5 0}$ 1293-1295

Friedman S, Gurevich $\mathbf{M}$ and Shemesh $\mathbf{M}$ (1995) Bovine cyclic endometrium contains high-affinity luteinizing hormone/human chorionic gonadotropin binding sites Biology of Reproduction 52 1020-1026

Godkin JD, Lifsey BJ and Gillespie BE (1988) Characterization of bovine conceptus proteins produced during the peri- and postattachment periods of early pregnancy Biology of Reproduction 38 703-711

Goodwin RG, Moncman CL, Rottman FM and Nilson JH (1983) Characterization and nucleotide sequence of the gene for the common $\alpha$ subunit of the bovine pituitary glycoprotein hormones Nucleic Acids Research 11 6873-6882

Hearn JP (1986) The embryo-maternal dialogue during early pregnancy in primates Journal of Reproduction and Fertility 76 809-819

Helmer SD, Hansen PJ, Anthony RV, Thatcher WW, Bazer FW and Roberts RM (1987) Identification of bovine trophoblast protein-1, a secretory protein immunologically related to ovine trophoblast protein-1 Journal of Reproduction and Fertility 79 83-91

Henricks DM, Dickey JF and Niswender GD (1970) Serum luteinizing hormone and plasma progesterone levels during the estrous cycle and early pregnancy in cows Biology of Reproduction 2 346-351

Hickey GJ, Walton JS and Hansel W (1989) Identification of a luteotrophic protein in bovine allantoic fluid Journal of Reproduction and Fertility Supplement 37 29-35

Hotakainen PK, Serlachius EM, Lintula SI, Alfthan HV, Schroder JP and Stenman UE (2000) Expression of luteinising hormone and chorionic gonadotropin beta-subunit messenger RNA and protein in human peripheral blood leukocytes Molecular and Cellular Endocrinology 25 79-85

Izhar $\mathbf{M}$ and Shemesh $\mathbf{M}$ (1989) Partial purification of a luteotrophic substance from bovine fetal cotyledon granules Journal of Reproduction and Fertility Supplement 37 37-44

Jensen JD and Odell WD (1988) Identification of LH/hCG receptors in rabbit uterus Proceedings of the Society for Experimental Biology and Medicine 189 28-30

Lanzillo JJ (1991) Chemiluminescent nucleic acid detection with digoxigeninlabelled probes: a model system with probes for angiotensin converting enzyme which detect less than one attomole of target DNA Analytical Biochemistry 194 45-53

Lee JJ and Costlow NA (1987) A molecular titration assay to measure transcript prevalence levels Methods in Enzymology 153 633-648

Lukaszewska J and Hansel W (1980) Corpus luteum maintenance during early pregnancy in the cow Journal of Reproduction and Fertility $\mathbf{5 9}$ 485-493

Maniatis T, Fritsch EF and Sambrook J (1982) Extraction, purification and analysis of mRNA from eukaryotic cells. In Molecular Cloning: A Laboratory Manual Chapter 6 pp 194-196. Cold Spring Harbor Laboratory, Cold Spring Harbor, NY

Maurer RA (1985) Analysis of several bovine lutropin $\beta$-subunit cDNAs reveals heterogeneity in nucleotide sequence Journal of Biological Chemistry $2604684-4687$

Nilson JH, Thomason AR, Cserbak MT, Moncman CL and Woychik RP (1983) Nucleotide sequence of a cDNA for the common $\alpha$-subunit of the bovine pituitary glycoprotein hormones Journal of Biological Chemistry 258 4679-4682

Pierce JG and Parsons TF (1981) Glycoprotein hormones: structure and function Annual Reviews in Biochemistry 50 465-495

Reshef E, Lei ZM, Rao CV, Pridham DD, Chegini N and Luborsky JL (1990) The presence of gonadotropin receptors in non-pregnant human uterus, human placenta, fetal membranes and decidua Journal of Clinical Endocrinology and Metabolism 70 421-430

Robinson NA, Leslie KE and Walton JS (1989) Effect of treatment with progesterone on pregnancy rate and plasma concentrations of progesterone in Holstein cows Journal of Dairy Science 72 202-207

Sambrook J, Fritsch EF and Maniatis T (1989) Extraction, purification and analysis of mRNA from eukaryotic cells. In Molecular Cloning: $A$ Laboratory Manual Chapter 7. Cold Spring Harbor Laboratory, Cold Spring Harbor, NY

SAS (1990) SAS User's Guide: Statistics SAS Institute Inc., Cary, NC

Sawitzke AL and Odell WD (1991) Uterine binding sites for LH/hCG can be modulated by hormonal status in rabbits and rats Acta Endocrinologica (Copenhagen) 124 322-330

Stefanovic V, Babic MS and Wartiovaara J (1993) Cell contacts in early human pituitary development Acta Anatomica 148 169-175

Stepien A, Shemesh M and Ziecik AJ (1999) Luteinizing hormone receptor kinetic and $\mathrm{LH}$-induced prostaglandin production throughout the oestrous cycle in porcine endometrium Reproduction, Nutrition and Development 39 663-674

Thibodeaux JK, Broussard JR, Godke RA and Hansel W (1994) Stimulation of progesterone production in bovine luteal cells by co-incubation with bovine blastocyst-stage embryos or trophoblastic vesicles Journal of Reproduction and Fertility 101 657-662

Virgin JB, Silver BJ, Thomason AR and Nilson JH (1985) The gene for the $\beta$ subunit of bovine luteinizing hormone encodes a gonadotropin mRNA with an unusually short 5'-untranslated region Journal of Biological Chemistry $2607072-7077$

Webley GE and Hearn JP (1994) Embryo-maternal interactions during the establishment of pregnancy in primates Oxford Reviews in Reproductive Biology 16 1-32

Ziecik AJ, Stanchev PD and Tilton JE (1986) Evidence for the presence of luteinizing hormone/human chorionic gonadotropin binding sites in the porcine uterus Endocrinology 119 1159-1163

Ziecik AJ, Jedlinska M and Rzucidlo SJ (1992) Effect of estradiol and progesterone on myometrial $\mathrm{LH} / \mathrm{hCG}$ receptors in pigs Acta Endocrinologica (Copenhagen) 127 185-188

Received 12 February 2001.

First decision 12 April 2001.

Final revision received 28 August 2001.

Accepted 2 October 2001. 